\title{
Transformation Of Forms And Functions Of Javanese Traditional House In Kauman Surakarta
}

\author{
IF.Bambang Sulistyono \\ ifbambang@staff.uns.ac.id \\ Interior Design Program \\ Faculty of Fine Arts and Designs \\ Universitas Sebelas Maret Surakarta \\ Jalan Ir. Sutami No. 36 A Surakarta 57126
}

\author{
Djoko Panuwun \\ panuwund@yahoo.com \\ Interior Design Program \\ Faculty of Fine Arts and Designs \\ Universitas Sebelas Maret Surakarta \\ Jalan Ir. Sutami No. 36 A Surakarta 57126
}

\begin{abstract}
Cultural transformations bring consequences to social, economic, and political changes that also bear influence and effect on the changes of traditional Javanese house forms and functions in Kauman Surakarta. The view changes on the values of Javanese house philosophy at the present time are mainly influenced by the attitude of the people who view that the beliefs related to the concept of Javanese cosmology are no longer relevant at the present time, so that there are shifts of values among the people who previously obeyed the tradition and local beliefs to become a modern society with life views and values that are more practical and efficient, as well as more rational in thinking. The shifts of these values have implications on the changing functions and meanings of traditional values contained in the symbolic elements of traditional Javanese house layout in Kampung Kauman Surakarta.
\end{abstract}

Keywords: traditional Javanese house, transformation of form, function

\section{INTRODUCTION}

In human life, the presence of a house as a place to live is inevitable. It becomes the environment and part of human life itself, which is not only a place to shelter from weather and climate disturbances, but also a place to rest or sleep, as well as a place to develop in life either as an individual, social or cultural creature (Rapopot, 1969 ) Considering the importance a house in the social life in the community, when viewed in terms of its function and meaning the form of a house structure as a traditional building can be used as a reflection of the level of technology, lifestyle and cultural values of the related community.

House as a traditional building with all forms and functions, and its cultural-specific meanings in the society are regulated, directed and responded to or treated by its residents according to the culture of the related community.

Traditional Javanese houses in Kauman Village, in the context of socio-culture, are inseparable from the functional relationship between the concepts that form the basis of their manifestations, both in terms of shape and spatial structure, as well as the factors that influence them. The community of Javanese people living in Kauman Village is historically known as a religious community, meaning that their daily lives are strongly influenced by the belief and value system as taught by their religion, namely Islam as the majority. Thus Kauman village is known as the village where santri (moslem scholar), Ulama and khotib (moslem religious leaders) and their courtiers live (Musyawaroh, 2001; Ma'mun Pusponegoro et al, 2006).

Thus, the existence of Kauman Village with its characteristics provides a distinctive culture that has aesthetic historical values, and specifications that reveal many forms and structures and symbols that provide cultural information of their time.

\section{RESEARCH OBJECTIVES}

This research was conducted to describe the factors that underlie the transformation of the shapes and functions of traditional Javanese houses in Kauman Village Surakarta.

\section{RESEARCH METHOD}

In line with the objectives of the study to describe findings comprehensively, the approach used in this study was descriptive qualitative approach. The data were collected from library sources, interviews with a number of informants from historical actors, especially Kauman community leaders and from academicians, especially in the field of architectural history, as well as field observations. Data analysis was conducted by flow of analysis method (Huberman in Sutopo, 2002) and to obtain the accuracy and validity of the data, triangulation of data was carried out by triangulating data from literature, informants and evidence of artifacts.

\section{RESULTS AND DISCUSSION}

\section{A. The History of Kauman Village}

Kauman is a name of a village that is always present in the spatial layout of cities in Java. The city planning system of the Javanese society in general has a basic form that is almost the same in every places for example, there is alway a form of city square surrounded by government centers and a grand mosque. The grand mosque are always 
surrounded by houses which are then called the Kauman village (Wijanarka, 1970: 9).

Seen from the terminology, the word Kauman in each city has different definitions but with the similar meaning. In Yogyakrta, Kauman is derived from the phrase "nggone wong kaum" which means its place of "kaum" people. In Kudus Kauman comes from the word "pakauman" meaning the residence of kaum people. Then in Semarang Kauman came from Arabic word, namely "qo'um muddin" which means the leaders of the Islamic religion. Thus it can be concluded that, Kauman is the residence of religious leaders. Then Darban (1984), asserted that the growth of the Kauman village had similar typologies in cities in Java with the main characteristic being a santri village in the city center.

The name of Kauman village in Surakarta has its own history, related to the existence of the Kasunanan Surakarta Palace. Kauman village was established at the same age as the construction of Surakarta Grand Mosque which was built during Pakubuwanan III period in 1757 AD. The mosque was established as a form of the king's obligation to lead his people where the king is also "Sayidin Panatagama Khalifatullah", which means that a king is also a religious leader so that the people can live in peace and prosperity. To carry out the duty of king as Sayidin Panatagama Khalifatullah, the king appointed and placed a penghulu (an expert on religion as well as an advisor to the king), namely Kanjeng Raden Tumenggung Pangeran Tafsir Anom.

The existence of Kauman village is also inseparable from the history of Kauman batik. At the beginning of the Kauman community only worked as courtiers especially Khotib (preacher). Besides being a Khotib, over time, the wives of courtiers also made batik to meet the needs of the palace. With a division pattern of labor which placed husbands in their duties as Khotib and their wives filling their time by producing batik with knowledge obtained from fellow courtiers. In its development, the batik skills are enhanced so that they can produce large amounts of batik cloth. So that they were able to increase the amount of production and developed into batik entrepreneurs who could improve the economic aspects of the Kauman community.

\section{B. Traditional Javanese House in Kauman Surakarta}

In traditional Javanese architecture, the pattern or arrangement of space is standardized. This can be observed that in all residences with traditional architecture, that traditional Javanese houses have the same pattern or arrangement, both in terms of hierarchy and space functions. A village that has historical value, generally always produces a specific architecture designs, likewise in the Kauman Surakarta village.
Typologically, the houses in Kauman village can be grouped into three types, namely (1) traditional Javanese house types in Joglo and Limasan forms, (2) Javanese house types that have been influenced by foreign (European) elements, namely Indis and Art- Deco, and (3) the type of ordinary houses that can be classified in the common village forms and other forms that are simpler and usually used by the general public.

Joglo or Limasan houses are mostly inhabited by batik masters and Khotib. In the past, the position of a khotib was seen by the public as a high position and was given to chosen people who had high religious knowledge. Therefore, a khotib has a high socioeconomic status besides being a courtier of the Palace. Khotib usually also has a wife who is also a batik enterpreneur.

The second group is houses in Indies and Art Deco forms, which most of them are also inhabited by batik bosses, whether they have kinship with khotib or not. The batik enterpreneurs are also a group of people who are respected and have a high social status. Architecturally the houses with Indies and Art Deco forms are combined forms between traditional Javanese houses and European architectural styles. The third group is houses with common village forms like ordinary houses in general.

Taken as a whole, basically the houses in Kauman village are houses that hierarchically have spatial patterns commonly found in traditional Javanese houses in general. This can be seen from the organizational structure of the space in the forms of a Joglo. Limasan, Indis / Art Deco, and common village house forms have the same spatial structure, such as pendopo, pringgitan, ndalem (sentong Tengah, kiwa and tengen), gandok and gadri.

Thus, it shows that the Javanese house space organization in Kauman village is still referring to the conception of traditional Javanese houses, although in its development it has experienced a shift from its original function. In the conception of Javanese house architecture, each space has different functions which are determined by the thoughts of the macrocosm and microcosm. This has logical consequences on the activities carried out in each space.

In addition, the conception of traditional Javanese architecture according to the meaning or value of the view of macrocosm and microcosm is divided into sequences from the general (profane) toward the specific and sacred. As expressed by Mangun Wijaya (1988, 106-113), that: All things that are intimate or sacred are called dalem or petanen (the place of the farmer) and those outside, the place where the residents associate with the community are named the pelataran or njaba (outer part). In this space a pendapa (hall) is built which is meant as an additional building where the host meet his guests. Thus the arrangement of the dalem which 
is sacred and pendapa which is profane shows how harmonious the dialectic is between vertical relations to God and horizontal relation to fellow humans.

This concept is a manifestation of the concept of macrocosm and microcosm which is expressed in the spatial pattern, namely in Petanen (Sentong Tengah) is the sacred part of the of the house (dalem). While the general (profane) part is called pendapa. Thus the philosophical meaning of pendapa is the the place where dialogue or communication between the owner of the house and relatives, neighbors and the general public happen and this is a reflection of the Javanese lifestyle which shows the atmosphere of "guyub rukun" (living together in harmony). This concept shows how Javanese people have a high attachment to kinship which is reflected in the form of harmony. The shape of Joglo has a deeper meaning, because the shape of the roof that rises upward shows the vertical direction towards one point, the Almighty and horizontally centers on the center under the roof, which is in the middle among the four main pillars (saka guru). Saka guru in addition to functioning as a roof support construction also functions as a support construction for the upper ceiling called tumpang sari. Saka guru has an important role in traditional Javanese house. It is the embodiment of the concept of "Macapat" or the concept of "Papat Kiblat" (the four directions of the compass) transformed into a rectangular form. The rectangular form is the concept of "Mandala" which in the pendapa plan describes the symbols of magicaltranscendental powers. While the Limasan form can be said to be almost non-existent and philosophically simpler, there is no tumpang sari and the construction consists of blandar, keret, ander, dudur, and molo. But the spatial concept has the same meaning as the Joglo house, either pendapa, pringgitan, or dalem.

\section{Transformation of Forms and Functions}

Cultural changes basically occur because of modifications in the components of ideas that are socially approved by the people of the supporting community (Suparlan, 1986: 116). Cultural change can be caused by the presence of environmental symptoms faced by the people which tend to change quickly, but because culture is a comprehensive guide to the lives of the related people, then culture is in fact traditional.

Cultural changes can occur in the content, structure, or configuration of certain ways of life, and they can also occur in the forms, functions, or values of the smallest or larger elements or even the institutions. Cultural change from the traditional to the modern and the resulted consequences bring a consequence to the social, cultural, economic and political changes. The imoact of cultural cahanges can also be seen in the forms and functions, as well as the meaning of traditional houses in general, especially Javanese traditional houses in Kauman village, Surakarta.

The Javanese view of human life oriented on the principles of harmony, kinship and prosperity in reality has not been shifted or does not change into other views according to modern views. Thus the life guidelines of the Kauman people are seen as a culture that does not change, but the changes that occur are changes in functions presented in other forms, such as pendapa which is functioned as a store used to display various batik products.

Likewise in other spaces such as pringgitan and dalem, it functions as a multipurpose room, in addition to being a place to live, it becomes a place for family activities, such as receiving guests, family gatherings, events related to marriage ceremonies, circumcisions, religious social activities and at the same time function as a shop, while gandok is used as a warehouse or other activity. This change in function is influenced by several factors, such as science and technology, economic growth, demands for space requirements, values, lifestyle and lifestyle of the people of Kauman. So that the orientation of the lifestyle of the people of the Kauman Surakarta community changes with the modern lifestyle.

With this change in attitudes and perspectives, transformation also takes place although the organizational structure of space remains the same, thus there are no significant changes. Changes in form occur in houses with Indis and Art Deco style that adopt Western cultural idioms. Physically, the building looks like a combination of Javanese houses and European architectural styles. But the factors that influence changes that occur, are still in context that has contributed to the sustainability of the existence of traditional Javanese houses.

\section{CONCLUSION}

Thus, the transformation that occurs in Javanese houses in Kauman village is a change in form and function. These changes are due to changes in views of traditional values in the present, which are mainly influenced by the attitude of people who think that beliefs related to the conception of Javanese cosmology are not relevant to the development of the times. Life views and values that are more inclined to practical and efficient attitudes and rational thinking, no longer see traditional Javanese houses with their spatial systems as homes that are sacred but more functional-economic.

But the real situation is that the existence of traditional Javanese houses in Kauman village is not a total loss. The spatial structure is maintained even though its religious function has been abandoned and replaced with new functions due to the need for economic and social functions and in its development, for tourism function. Thus the original function has shifted into a more diverse functions. This has implications that the symbolism of 
traditional Javanese values contained in the spatial structure and its constituent elements are not interpreted as symbols that contain philosophical meanings, but as in the modern point of view which emphasizes on practicality, efficiency and effectiveness of their usefulness.

Another factor is the influence of religion, in which Kauman village is known as the village of santri (moslem scholars), almost all of its citizens adhere to the religion of Islam that strongly influence the daily life of the people. So that their attitudes and behavior in meeting their various needs of life are always guided by the beliefs and value systems derived from the teachings of Islam as the main normative reference. Thus it is directly and indirectly influential to the changing view on traditional Javanese values.

This phenomenon is implicitly and explicitly manifested in the change in forms and functions and the provision of meaning to the traditional Javanese house layout in Kauman village. Likewise regarding to the influence of science and technology, where Kauman village is a village located in the middle of a city that is geographically close to urban culture that can reconstruct the mindset of Kauman community.

Thus it can be concluded, that over time the life views of the people living in Kauman village of Surakarta towards their traditional values have changed. The changes in the value system of people's lives have brought consequences on social, cultural, economic and political changes which result in the changing forms and functions of traditional Javanese house layout in Kauman Village Surakarta.

\section{REFERENCES}

Darban, Ahmad Adaby, 2000, Sejarah Kauman Menguak Identitas Kampung Muhammadiyah, Terawang, Yogyakarta.

Musyawaroh, 2000, Deskripsi Tata Fisik Rumah Pengusaha Batik di Kauman Surakarta, Tesis S2, UGM.

Makmun Pusponegara dkk, 2006, Kauman Religi, Tradisi, dan Seni, Surakarta: Kampung Batik Kauman.

Mangunwijaya, YB, 1992, Wastu Citra, Pengantar Ilmu Budaya Bentuk Arsitektur Sendi-Sendi filsafatnya, Jakarta: PT Gramedia Pustaka Utama.

Rapopot, Amos, 1969, House, Form, and Culture, Englewood Cliffs, NY: Pretica Hall, Inc.

Suparlan, 1981-1982, Kebudayaan, Masyarakat, dan Agama : Agama Sebagai Sarana Penelitian Antropologi, Dalam Majalah Ilmu-Ilmu Sastra Indonesia Jakarta: Fakultas Sastra UI.

Sutopo, 2002. Metodologi Penelitian, Surakarta, UNS Press.

Wijanarka, 2007, Semarang Tempu Dulu, Teori Desain Kawasan Bersejarah, Yogyakarta: Ombak. 